\title{
POTENSI ANTIPIRETIK EKSTRAK ETANOL DAUN COCOR BEBEK (KALANCHOE PINNATA L.)
}

\author{
Tari Maulidina I.P*, Risna Agustina, Laode Rijai \\ Laboratorium Penelitian dan Pengembangan FARMAKA TROPIS \\ Fakultas Farmasi Universitas Mulawarman, Samarinda, Kalimantan Timur \\ *email: maulidinatari@gmail.com
}

\begin{abstract}
Kalanchoe pinnata was found to have various pharmacological activity such as wound healing, antidiabetic, anti-inflammatory and analgesic, even empirically as an antipyretic. Prostaglandin as one of the inflammation mediators, known to have a role in the process of pyrexia. A number of active compound groups including flavonoids, polyphenols and triterpenoids has been reported as a responsible substance for these activity. This study investigated the antipyretic activity of ethanol extract of K.pinnata leaf on rats. Pyrexia was induce by injection of yeast subcutaneously. Observations of rising body temperature on rats and the treatment performed after 16 hours. Positive control was treated with paracetamol while the test was treated with extract $(100 \mathrm{mg} / \mathrm{kg}, 200 \mathrm{mg} / \mathrm{kg}$ and $300 \mathrm{mg} / \mathrm{kg}$ ) orally. The results showed that the leaf extract of K.pinnata with a dose of $100 \mathrm{mg} / \mathrm{kg}$ and $200 \mathrm{mg} / \mathrm{kg}$ were able to lower the body temperature of rats while $300 \mathrm{mg} / \mathrm{kg}$ doses showed no activity.
\end{abstract}

Keywords: Antipyretic, Kalanchoe pinnata, yeast

\begin{abstract}
ABSTRAK
Kalanchoe pinnata diketahui memiliki berbagai macam aktivitas farmakologi antara lain penyembuh luka, anti-diabetes, anti-inflamasi dan analgesik yang baik, bahkan secara empiris efektif sebagai antipiretik. Prostaglandin sebagai salah satu mediator nyeri, juga turut berperan dalam mekanisme terjadinya pireksia. Senyawa aktif yang diduga bertanggungjawab terhadap aktivitas ini antara lain adalah flavonoid, polifenol, dan triterpen. Telah dilakukan penelitian untuk melihat efek antipiretik dari ekstrak etanol daun cocor bebek terhadap tikus. Induksi pireksia dilakukan dengan menginjeksikan suspensi ragi (bakers' yeast) pada tikus secara subkutan. Kenaikan suhu tubuh tikus diamati setelah 16 jam dan setelahnya diberikan perlakuan. Kontrol positif diberikan parasetamol sedangkan kelompok uji diberikan ekstrak dengan dosis $100 \mathrm{mg} / \mathrm{kg}, 200 \mathrm{mg} / \mathrm{kg}$ dan $300 \mathrm{mg} / \mathrm{kg}$. secara oral. Hasilnya menunjukkan bahwa ekstrak etanol daun cocor bebek pada dosis $100 \mathrm{mg} / \mathrm{kg}$ dan $200 \mathrm{mg} / \mathrm{kg}$ mampu menurunkan suhu tubuh tikus sedangkan dosis $300 \mathrm{mg} / \mathrm{kg}$ tidak menunjukkan aktivitas penurunan suhu tubuh tikus.
\end{abstract}

Kata kunci: Antipiretik, Kalanchoe pinnata, ragi 


\section{PENDAHULUAN}

Meskipun proses signifikan dari mekanisme termoregulasi telah diketahui sejak 30 tahun lalu, akan tetapi berbagai agen antipiretik yang aman dan efektif yang tersedia di pasaran sebenarnya tidak mengalami perubahan selama periode tersebut (Tomazetti, 2005). Demam merupakan gejala yang sering dialami manusia, ditandai dengan kenaikan suhu tubu seseorang di atas batas normal. Demam dapat menyebabkan rusaknya otak secara permanen dan dapat menyebabkan kematian bila suhu tubuh seseorang sangat tinggi. Obat-obat antipiretik yang sering digunakan untuk mengobati demam yaitu parasetamol, asetosal dan sejenisnya (Moot, 2013).

Kalanchoe pinnata (Lamarck), salah satu spesies medisinal paling umum dari famili Crassulaceae, digunakan oleh masyarakat luas sebagai alternatif pengobatan dari banyak macam penyakit seperti disfungsi kardiovaskular, diabetes, penyembuhan luka dan mengobati inflamasi. Daun dari tumbuhan ini merupakan bagian yang paling umum digunakan dan oleh karena itu telah banyak studi yang fokus pada berbagai senyawa kimia dan aktivitas farmakologi yang dimilikinya (Ferreira, 2014).

Ekstrak air dari B. pinnatum dapat memberikan potensi efek analgesik yang kuat dibandingkan perlakuan secara time dan dose-dependent dengan obat antiinflamasi non steroid. Hasil investigasikan membuktikan bahwa ekstrak air tidak memiliki efek toksik yang parah, meningkatkan ambang batas nyeri pada tikus menggunakan hot plate atau metode thermal, menghambat atau mengurangi geliat yang diinduksi fenilbenzokuinon atau peregangan abdominal pada mencit dengan perlakuan dose-dependent serta menghasilkan aktivitas antiinflamasi yang lebih rendah dari aspirin (Pattewar, 2012).

Karena efek analgesik yang besar inilah, ekstrak daun cocor bebek dicurigai juga memiliki efek antipiretik. Hal ini didasarkan oleh mediator analgesik dan demam yang sama yaitu prostaglandin. Prostaglandin merupakan salah satu mediator nyeri dengan berbagai target lokasi, salah satunya adalah hipotalamus yaitu bagian pada otak yang mengatur suhu tubuh.

\section{METODE PENELITIAN}

Alat

Termometer digital, jarum suntik, spoit, timbangan hewan, sonde, timbangan analitik, rotary evaporator, lumpang dan alu, labu ukur, beaker gelas.

\section{Bahan}

Aquadest, etanol, parasetamol, $\mathrm{Na} \mathrm{CmC}$, larutan normal saline, ragi, kapas, alkohol $70 \%$.

\section{Prosedur}

\section{Proses Ekstraksi}

Simplisia bersih diletakkan di dalam wadah kaca kemudian dimasukkan pelarut etanol sebanyak 2 liter ke dalamnya. Proses ekstraksi dilakukan selama $3 \times 24$ jam, larutan ekstrak kemudian disaring untuk memisahkan maserat dari residu. Kemudian proses perendaman diulangi hingga warna pelarut tetap bening. Maserat kemudian dimasukkan ke dalam rotary evaporator untuk menguapkan pelarut dan diperoleh ekstrak kental. 


\section{Penyiapan Hewan Uji}

Sebanyak 20 tikus putih dikarantina selama seminggu sebelum pengujian. Diberi makan dan minum standar. Sebelum perlakuan pengujian suhu tubuh tikus diukur pada bagian rektal menggunakan termometer dan dicatat. Hanya tikus dengan suhu tubuh normal yang kemudian termasuk ke dalam pengujian dan dipuasakan selama 12 jam sebelum pengujian.

\section{Penyiapan Ekstrak}

Ekstrak kental yang telah ditimbang sesuai dosis disuspensikan dengan $\mathrm{Na} \mathrm{cmc} 1 \%$. Suspensi ekstrak kemudian dimasukkan ke dalam labu ukur $10 \mathrm{~mL}$ dan ditambahkan aquades hingga tanda batas. Hasilnya didapatkan dosis ekstrak daun cocor bebek sebesar $100 \mathrm{mg} / \mathrm{kg}, 200 \mathrm{mg} / \mathrm{kg}$ dan $300 \mathrm{mg} / \mathrm{kg}$.

\section{Induksi}

Sebelum induksi dicatat suhu tubuh tikus. Induksi dilakukan dengan menginjeksikan suspensi ragi 20\% dalam larutan normal saline secara subkutan. Suhu tubuh tikus diukur dan dicatat kembali setelah $16 \mathrm{jam}$. Suhu tubuh tikus yang mengalami kenaikan minimal $0.3{ }^{\circ} \mathrm{C}$ dari suhu awal sebelum induksi digunakan sebagai uji.

\section{Pengujian}

Suspensi ekstrak diberikan secara per oral disesuaikan dengan bobot tikus uji. Untuk kontrol negatif dapat diberikan aquades secara per oral dengan jumlah yang sama, sedangkan untuk kontrol positif diberikan suspensi parasetamol per oral. Suhu tubuh tikus setelah perlakuan diukur dalam beberapa interval waktu (menit ke 30, 60, 90 dan 120). Hasil penurunan suhu tubuh tikus yang diperoleh kemudian dibandingkan antara kelompok uji dan kontrol positif.

\section{HASIL DAN PEMBAHASAN}

Demam merupakan respon tubuh terhadap infeksi maupun molekul asing di dalam tubuh. Ditandai dengan meningkatnya prostaglandin di area spesifik di otak yang memicu peningkatan suhu tubuh. Prostaglandin memiliki peran yang signifikan di dalam proses terjadinya demam. Mekanisme demam terjadi ketika pembuluh darah di sekitar hipotalamus terkena pirogen eksogen tertentu, maka mtabolit asam arakidonat dilepaskan dari endotel sel ke jaringan pembuluh darah. Metabolit seperti prostaglandin akan melintasi barrier darahotak dan meyebar ke dalam pusat pengaturan suhu di hipotalamus. Lepasnya prostaglandin menyebabkan pusat termoregulasi di hipotalamus mengalami perubahan yaitu dengan menaikkan set point nya. Dengan titik set point yang telah ditentukan, hipotalamus akan mengirimkan sinyal simpatis ke pembuluh darah perifer. Pembuluh darah perifer akan merespon dengan melakukan vasokontriksi yang menyebabkan penurunan heat-loss melalui kulit. Akibatnya suhu tubuh meningkat terus menerus seiring masih dilepaskannya prostaglandin ke bagian hipotalamus.

Ekstrak etanol daun cocor bebek diketahui memiliki aktivitas analgesik yang kuat dibandingkan dengan NSAID berdasarkan perlakuan secara time-dependent. Flavonoid dicurigai sebagai senyawa fitokimia yang bertanggungjawab atas aktivitas analgesik, antiinflamasi bahkan antipiretik. Sedangkan parasetamol sebagai agen antipiretik bekerja dengan cara menghambat pelepasan prostaglandin dalam proses terjadinya pireksia. Ekstrak cocor bebek yang diujikan sebagai agen antipiretik dapat dikatakan memiliki mekanisme yang sama dengan parasetamol dalam menurunkan suhu tubuh. Ekstrak mengembalikan pengaturan termoregulasi yang berubah selama proses terjadinya demam. 
Pengujian antipiretik dilakukan dengan menginduksi suspensi ragi $20 \%$ secara subkutan. Setelah 16 jam suhu tubuh tikus mengalami kenaikan akibat dari induksi. Ragi (Saccharomyces cereviceae) sebagai agen penginduksi memiliki molekul yang besar. Saat diinjeksikan secara subkutan pada tikus, molekul ragi yang besar ini dapat memicu proses pertahanan tubuh terhadap molekul asing. Sistem imun merespon ragi sebagai pirogen eksogen yang kemudian memicu demam.

Data aktivitas antipiretik ekstrak daun cocor bebek dapat dilihat pada Tabel 1.

Tabel 1. Aktivitas antipiretik ekstrak daun cocor bebek.

\begin{tabular}{cccccc}
\hline Hewan Uji & 1 & 2 & 3 & 4 & 5 \\
\hline SA* $^{*}$ & 36,7 & 37,0 & 36,8 & 35,8 & 37,0 \\
SS $^{*}$ & 38,2 & 38,7 & 38,4 & 38,1 & 37,3 \\
$30^{\prime}$ & 38,2 & 38,0 & 38,4 & 37,9 & 37,3 \\
$60^{\prime}$ & 38,2 & 37,7 & 37,3 & 37,3 & 37,3 \\
$90^{\prime}$ & 38,1 & 37,0 & 37,1 & 37,1 & 37,2 \\
$120^{\prime}$ & 38,1 & 37,0 & 36,8 & 36,6 & 37,2
\end{tabular}

(Suhu dalam $\left.{ }^{\circ} \mathrm{C}\right) . *$ SA: Suhu awal; *SS: Suhu setelah induksi; 1: Kontrol negatif; 2: Kontrol positif; 3: Dosis $100 \mathrm{mg} / \mathrm{kg}$; 4: Dosis $200 \mathrm{mg} / \mathrm{kg}$; 5: Dosis $300 \mathrm{mg} / \mathrm{kg}$

Berdasarkan data yang diperoleh, dosis ekstrak daun cocor bebek sebesar $100 \mathrm{mg} / \mathrm{kg}$ dan $200 \mathrm{mg} / \mathrm{kg}$ mampu menghasilkan efek penurunan suhu tubuh tikus. Pada dosis 100 $\mathrm{mg} / \mathrm{kg}$ suhu tubuh mengalami penurunan di menit ke 60 setelah perlakuan. Penurunan suhu tubuh tikus terus terjadi hingga menit ke 120 . Pada dosis $200 \mathrm{mg} / \mathrm{kg}$ suhu tubuh tikus mengalami penurunan pada menit ke 30 setelah perlakuan dan terus mengalami penurunan hingga menit ke 120 . Sedangkan pada dosis $300 \mathrm{mg} / \mathrm{kg}$ suhu tubuh tikus tidak mengalami penurunan yang siginifikan jika dibandingkan dengan kelompok uji yang lain. Dosis ekstrak $100 \mathrm{mg} / \mathrm{kg}$ bekerja efektif memberikan aktivitas antipiretik pada menit ke 60 dan kemampuan mengembalikan suhu tubuh tikus menjadi normal (suhu tubuh tikus sebelum induksi) sedangkan dosis $200 \mathrm{mg} / \mathrm{kg}$ bekerja lebih cepat dengan menurunkan suhu tubuh tikus di menit ke 30 setelah perlakuan yang mana waktu penurunan ini sama dengan waktu yang dibutuhkan kontrol positif yaitu parasetamol dalam menurunkan suhu tubuh tikus. Dosis $300 \mathrm{mg} / \mathrm{kg}$ tidak memiliki aktivitas antipiretik karena tidak menunjukkan penurunan suhu tubuh tikus yang cukup. Dosis $300 \mathrm{mg} / \mathrm{kg}$ ini diduga lebih mengarah sebagai antiinflamasi (Pattewar, 2012). Sehingga dapat dikatakan ekstrak daun cocor bebek memiliki aktivitas antipiretik dengan onset kerja yang sama dengan parasetamol (dalam waktu $1 \mathrm{jam}$ ), meskipun durasi kerja nya tidak sepanjang parasetamol. Hal ini didasarkan atas perbandingan suhu tubuh tikus kontrol negatif dengan uji. Pada tikus kontrol negatif, suhu tubuh tikus setelah induksi tidak mengalami penurunan hingga menit ke 120. Berdasarkan literatur, kondisi pireksia yang diakibatkan oleh induksi ragi dapat bertahan hingga 6 jam. Akan tetapi ekstrak daun cocor bebek dapat mempengaruhi kondisi pireksia dengan menurunkan suhu tubuh tikus dalam waktu 30 menit dan bertahan hingga 120 menit. Setelah menit ke-120, suhu tubuh tikus kembali mengalami kenaikan. Kondisi ini dapat terjadi karena agen penginduksi kemungkinan masih mempengaruhi fungsi biologis tubuh tikus.

\section{KESIMPULAN}

Ekstrak daun cocor bebek berpotensi sebagai agen antipiretik dengan dosis 100 $\mathrm{mg} / \mathrm{kg}$ dan $200 \mathrm{mg} / \mathrm{kg}$. Waktu yang dibutuhkan ekstrak dalam menurunkan suhu tubuh sama dengan onset kerja dari parasetamol. 


\section{DAFTAR PUSTAKA}

1. Tomazetti, J., et al. 2005. Baker Yeast-Induced Fever In Young Rats: Characterization and Validation of An Animal Model for Antipyretics Screening. Journal of Neuroscience Methods. 147. 29-35.

2. Moot, C. L., Bodhi, W. dan Mongi, J. 2013. Uji Efek Antipiretik Infusa Daun Sesewanua (Clerodendron squamatum Vahl.) Terhadap Kelinci Jantan yang Diinduksi Vaksin DTP HB. Jurnal Ilmiah Farmasi - UNSRAT. 2. (3). 2302-2493.

3. Ferreira, R. T., Coutinho, M. A. S., et al. 2014. Mechanisms Underlying the Antinociceptive, Antiedematogenic, and Anti-Inflammatory Activity of The Main Flavonoid from Kalanchoe pinnata. Evidence-Based Complementary and Alternative Medicine.

4. Pattewar, S. V. 2012. Kalanchoe pinnata: Phytochemical and Pharmacological Profile. IJSPR. 3. (4). 993-1000. 